\title{
Pharmacological potential of Ulva species: a valuable
} resource

\begin{abstract}
With the emergence of new diseases, the increase of pathogenic strains resistance and the apprehensiveness of synthetic compounds side effects, there is a constant need to find natural and low toxicity drug candidates. Seaweeds are rich source of original and bioactive natural substances. In particular, species of the genus Ulva have been demonstrated to metabolize biomolecules with pharmacological potential. This mini review present some of the biological properties reported for Ulva spp.
\end{abstract}

Keywords: green seaweed; Ulva, antibacterial, anti-inflammatory, cytotoxic, antiviral, Antiprotozoal, antioxidant
Volume 6 Issue I - 2017

\section{Leila Ktari}

National Institute of Marine Sciences and Tecnologies (INSTM), Tunisia

Correspondence: Leila Ktari, National Institute of Marine Sciences and Technologies - INSTM, 28, Rue du 2 mars, Salammb, Tel 2.1607IE+II, Fax 2.1607|E+II,

Email Leila.ktari@instm.rnrt.tn

Received: August 28, 2017 | Published: September 06, 2017

\section{Introduction}

Ulva Linnaeus genus (Ulvaceae, Ulvales) is an ubiquitous genera widely distributed in oceans and estuaries. Currently, 128 species (accepted taxonomically) have been listed all around the world. ${ }^{1}$ Individuals of this genus are characterized by a broad range of environmental tolerance, high growth rate and photosynthetic activity leading to a relatively abundant natural biomass. Aditionnaly, in a rich nutrient environment, these species can proliferate into green tides, making available important amounts of biomass. ${ }^{2}$ On the other hand, the successful results obtained for Ulva spp. cultivation in integrated multitrophic aquaculture (IMTA) systems ${ }^{3}$ or in land based aquaculture coupled with waste water bioremediation [4] allows promising development for sustainable raw material supply. This last decade, scientific interest for this taxonomic genus has increased. ${ }^{5}$ The cosmopolitan nature of Ulva spp., its development patterns and plasticity, among other reasons make it a good model organism to study algal growth, development and morphogenesis. ${ }^{6}$ From an economic perspective, the use of Ulva species for different applications has been largely described: bioremediation, ${ }^{7}$ bioenergy, ${ }^{8}$ food and feed. ${ }^{9}$ A biorefinery approach for industrial exploitation of Ulva constituents have been proposed. ${ }^{10}$ To realize an economically feasible value chain, cascading valorization of both protein and nonprotein seaweed constituents is required. We here present a mini review of pharmacological perspectives for species of the genus Ulva.

\section{Antibacterial and antifungal}

The constant increase of pathogenic microbes resistance to existing antibiotics led to the continual need to find new antibacterial candidates. Marine algae derivatives seem to be good candidates in novel, antibacterial drug discovery. ${ }^{11}$ Antimicrobial properties of Ulva species have been widely studied. Crude extracts of Ulva spp. samples often displayed positive antibacterial and/or antifungal activities for samples collected from different parts of the world. ${ }^{12-14}$ In some studies, the actives compound have been isolated and identified. As for example, two guaiane sesquiterpenes derivatives from Ulva fasciata have been described with significant antibacterial activity against Vibrio parahaemolyticus. ${ }^{12}$

Recently ${ }^{15}$ demonstrated that time of harvesting of the algae can influence the antibacterial activity. In fact, these authors reported that
U. lactuca methanolic extracts inhibit a range of clinically relevant Staphylococcus strains. Moreover, the study showed that lunar phase of macrolagae harvest significantly impacts antimicrobial activity, suggesting that antimicrobial properties can be maximized by manipulating time of algal harvest.

It's worth to mention the use of Ulva extracts to synthesize nanoparticules. ${ }^{16,17}$ This technique, is a novel and innovative area of research for biomedical applications. As for example, the study of antifungal potency of silver (Ag-NP) synthesized by Ulva rigida aqueous extract tested on different human pathogens and with significant activity obtained on Aspergilus fumigates. ${ }^{18}$

\section{Anti-inflammatory}

Anti-inflammatory activity of species from Ulva genus have been reported in different studies. Ulva rigida collected from Tunisian coasts showed a significant inhibition of phospholipase A2 activity (PLA2 of Apis melifera). The bioassay guided fractionation of dichloromethane/methanol extract led to the isolation and identification of sulfoquinovosyldipalmitoyl glyceride as the active molecule with an IC50 of $125 \mu \mathrm{M} .{ }^{19}$

A steroid, the 3-O- $\beta$-D glucopyranosyl-stigmasta-5,25-dien isolated from Ulva lactuca, showed topical antiinflammatory activity when tested on the mouse ear oedema assay. ${ }^{20}$ Organic extracts of Ulva conglobatadisplayed neuroprotective and anti-inflammatory effects on murine hippocampal and microglial cells. ${ }^{21} U$. reticulata presented potent analgesic and anti-inflammatory effects in both acetic acid-induced writhing and hot plate-induced pain models, without significant toxic effect at highest possible doses. ${ }^{22}$ More recently, sulfated polysaccharide fraction from Ulva lactuca (collected from atlantic coasts from Brazil) displayed significant analgesic and antiinflammatory action. ${ }^{23}$ The authors demonstrated that the antinoceptive and anti-inflammatory action occurs through a peripheral mechanism: the bradykinin pathway.

\section{Cytotoxic}

There are several studies that demonstrate the cytotoxic potential of Ulva species. Methanol extract of Ulva fasciata collected from Indian coasts exhibited significant cytotoxic activity on hepatocyte carcinoma cells lines (Hep-G2) with optimum inhibition obtained at 
$170 \mu \mathrm{g} / \mathrm{ml} .{ }^{24}$ Additionnaly, ethanolic extract of Ulva rigida collected from Marmara Sea shores possess a strong antigenotoxic, chemoprotective effects on mutagenic agent MMC in vitro. ${ }^{25}$ These authors conclude that the obtained results for $U$. rigida extract (antigenotoxic and anti-clastogenic) are of great significance in radioprotection and thus may be useful in human pathological conditions. More recently, cytotoxic activity against three human cancer cell lines (HepG2, MCF7, and Hela) have been attributed to ulvan fraction extracted from Ulva lactuca collected from Vietnam coasts. ${ }^{26}$

\section{Antiviral}

First mention of antiviral properties of Ulva spp. have been made in early nineties, ${ }^{27}$ with a bioactive sphingosine from Ulva fasciata collected from West coast of India. The extract showed antiviral activity against Semeliki Forest Virus (SFV) at $20 \mathrm{mg} / \mathrm{mouse} / 7$ days.

Ulva rigida water extracts inhibited significantly the reproduction of influenza virus (A/Aichi (H3N2)) also in fertile eggs. ${ }^{28}$ The study pointed that Ulva rigida extract reduced the mortality rate of white mice in experimental influenza infection when applied orally and extended the time of survival. Extracts of Ulva fasciata, collected from Brazilian coasts have been evaluated on the replication of human metapneumovirus (HMPV). ${ }^{29}$ The results demonstrated that the majority of the extracts possess virucidal activity and therefore have the ability to interact with the extracellular viral particles and prevent the infection. Ulvan, that are sulfated polysacahride, have been described to have antiviral properties. The ulvan antiviral activity was tested using syncytia formation against paramyxovirus infection, exhibiting significant activity with an IC50 of $0.1 \mu \mathrm{g} / \mathrm{ml} .{ }^{30} \mathrm{In}$ addition, significant antiviral activities against Herpes simplex virus type1 from $U$. armoricana extract have been described. ${ }^{31}$ The revealed activities were correlated to high amounts of rhamnose, uronic acids and sulfate groups which are the main constituents of ulvans.

\section{Antiprotozoal}

Even thought antiprotozoal properties of seaweeds is understudied, some interesting findings can be reported for Ulva spp. Seaweed crude extracts of Ulva reticulata and Ulva rigida have been documented to exhibit strong in vitroactivity against the promastigote form of Leshmania major with IC50 of $64.75 \mu \mathrm{g} / \mathrm{ml}$ and $65.69 \mu \mathrm{g} / \mathrm{ml}$ respectively. ${ }^{32}$ Leishmanicidal potential of different marine and fresh macrophytes have been reported ${ }^{33}$ highlighting the antiprotozoal potential of Ulva lactuca extract. In fact, U. lactuca displayed the most potent activity against axenic amastigotes of Leshmania donovaniwith IC $50=5.9 \mathrm{ml} / \mathrm{ml}$ and efficiently inhibited the FabI enzyme. The antiprotozoal activity of four green marine algae collected from british coasts, among which two Ulva species ( $U$. intestinalis and $U$. lactuca) have been prospected. ${ }^{34}$ All crude extracts showed positive antiprotozoal activity against Trypanosomabruceirhodesiense while a moderate trypanocidal activity against Trypanosomacruzirupestrishave been obtained for $U$. lactuta extract.

\section{Other}

Last but not least, the antioxidant property of species of the genus Ulva has to be described since this make them candidates for several pathologies in which the oxidative stress is incriminated (neurological disorders, atherosclerosis, hypertension, acute respiratory distress, idiopathic pulmonary fibrosis, asthma, cancer, etc.). The antioxidant properties of Ulva spp. have been studied form species collected from different part of the world..$^{10,35,36}$ As for example, the antioxidant activity, contents of total phenolics and flavonoids were quantified in the methanolic extracts of four Ulva species. ${ }^{37}$ Ulva clathrata demonstrated the greater antioxidant potential with a low $\mathrm{IC}_{50}$ of $0.881 \mathrm{mg} / \mathrm{ml}$ corresponding also to the highest phenolic and flavonoid content $(5.080 \mathrm{mg} \mathrm{GAE} / \mathrm{g}$ and $33.094 \mathrm{mg} \mathrm{RE} / \mathrm{g}$ respectively). In addition, the free radical scavenging effects of hot water extract of Ulva reticulata obtained on animal model studies highlighted the possible use of this specie to reduce hepatic oxidative stress. ${ }^{38}$

\section{Conclusion}

This mini review just sketches the potential of Ulva species for pharmacological use. This report reinforce the claims that seaweeds, and in particular species of the genus Ulva, can be used in heath industry. Additionally, Ulva species, with their wide range of application fields, their relatively abundant natural biomass, that can also be cultivated in a sustainable way, constitute good candidates for Blue Biotechnology development.

\section{Conflicts of interest}

Author declare that there is no conflict of interest.

\section{References}

1. Guiry MD, Guiry GM. Algae Base. World-wide electronic publication, National University of Ireland, Galway, Ireland. 2017.

2. Smetacek V, Zingone A. Green and golden seaweed tides on the rise. Nature. 2013;504:84-88

3. Marinho G, Nunes C, Sousa-Pinto I, et al. The IMTA-cultivated Chlorophyta Ulva spp. as a sustainable ingredient in Nile tilapia (Oreochromis niloticus) diets. Journal of Applied Phycology. 2013;25(5):1359-1367.

4. Lawton RJ, Mata L, de Nys R, et al. Algal bioremediation of waste waters from land-based aquaculture using Ulva: selecting target species and strains. PloS One. 2013;8(10):e77344.

5. Silva M, Vieira L, Almeida AP. The Marine Macroalgae of the Genus Ulva: Chemistry, Biological Activities and Potential Applications. Oceanography. 2013;1:101.

6. Wichard T, Charrier B, Mineur F, et al. The green seaweed Ulva: a model system to study morphogenesis. Front Plant Sci. 2015;6:72.

7. Sode S, Bruhn A, Balsby TJS, et al. Bioremediation of reject water from anaerobically digested waste water sludge with macroalgae (Ulva lactuca, Chlorophyta). Bioresource Technology. 2013;146:426-435.

8. Bruhn A, Dahl J, Nielsen HB, et al. Bioenergy potential of Ulva lactuca: biomass yield, methane production and combustion. Bioresour Technol. 2011;102(3):2595-2604.

9. Abdel-Warith AWA, Younis ESMI, Al Asgaha NA. Potential use of green macroalgae Ulva lactuca as a feed supplement in diets on growth performance, feed utilization and body composition of the African catfish, Clarias gariepinus. Saudi J Biol Sci. 2013;23(3):404-409.

10. Bikker P, van Krimpen MM, van Wikselaar P, et al. Biorefinery of the green seaweed Ulva lactuca to produce animal feed, chemicals and biofuels. J Appl Phycol. 2016;28(6):3511-3525.

11. Shannon E, Abu-Ghannam N. Antibacterial Derivatives of Marine Algae: An Overview of Pharmacological Mechanisms and Applications. Mar Drugs. 2016;14(4):81-104.

12. Chakraborty K, Paulraj R. Sesquiterpenoids with free-radicalscavenging properties from marine macroalga Ulva fasciata Delile. Food Chem. 2010;122:31-41. 
13. Trigui M, Gasmi L, Zouari I, et al. Seasonal variation in phenolic composition, antibacterial and antioxidant activities of Ulva rigida (Chlorophyta) and assessment of antiacetylcholinesterase potential. Journal of Applied Phycology. 2013;25(1):319-328.

14. Boisvert C, Beaulieu L, Bonnet C, et al. Assessment of the Antioxidant and Antibacterial Activities of Three Species of Edible Seaweeds Journal of Food Biochemistry. 2016;39(4):377-387.

15. Deveau AM, Miller-Hope Z, Lloyd E, et al. Antimicrobial activity of extracts from macroalgae Ulva lactuca against clinically important Staphylococci is impacted by lunar phase of macroalgae harvest. Lett Appl Microbiol. 2016;62(5):363-371.

16. Rahimi Z, Yousefzadi M, Noori A, et al. Green Synthesis of Silver Nanoparticles using Ulva flexousa from the Persian Gulf, Iran. Journal of the Persian Gulf (Marine Science). 2015;5(15):9-16.

17. Fernández-Díaza C, Costea O, Maltab E-j. Polymer chitosan nanoparticles functionalized with Ulva ohnoi extracts boost in vitro ulvan immunostimulant effect in Solea senegalensis macrophages. Algal Research. 2016;26:135-142.

18. El-Kassas HY, ElKomi MM. Biogenic Silver Nanoparticles using Seaweed Ulva rigida and their Fungicidal and Cytotoxic Effects. JKAU, Mar Sci. 2015;25(1):3-20.

19. Ktari L. Recherche de composés actifs dans les algues marines: propriétés pharmacologiques et simulation de cycle biologique de l'algue et de la biosynthèse d'un métabolite. Paris VI University, France, 2000. p. 140.

20. Awad NE. Biologically active steroid from the green alga Ulva lactuca. Phytother Res. 2000;14(8):641-643.

21. Jin DQ, Lim CS, Sung JY, et al. Ulva conglobata, a marine algae, has neuroprotective and anti-inflammatory effects in murine hippocampal and microglial cells. Neurosci Lett. 2006;402(1-2):154-158.

22. Hong DD, Hien HM, Anh HTL. Studies on the analgesic and anti-inflammatory activities of Sargassum swartzii (Turner) C. Agardh (Phaeophyta) and Ulva reticulata Forsskal (Chlorophyta) in experiment animal models. African Journal of Biotechnology. 2011;10(12):2308-2314.

23. De Araújo, Rodrigues JA, Quinderé AL, et al. Analgesic and antiinflammatory actions on bradykinin route of a polysulfated fraction from alga Ulva lactuca. Int J Biol Macromol. 2016;92:820-830.

24. Das MK, Sahu PK, Rao GS, et al. Application of response surface method to evaluate the cytotoxic potency of Ulva fasciata Delile, a marine macro alga. Saudi J Biol Sci. 2014;21(6): 539-546.

25. Celikler S, Yildiz G, Vatan O, et al. In vitro antigenotoxicity of Ulva rigida C. Agardh (Chlorophyceae) extract against induction of chromosome aberration, sister chromatid exchange and micronuclei by mutagenic agent MMC. Biomed Environ Sci. 2008;21(6):492-498.
26. Thanh TT, Quach TM, Nguyen TN, et al. Structure and cytotoxic activity of ulvan extracted from green seaweed Ulva lactuca. Int J Biol Macromol. 2016;93:695-702.

27. Garg HS, Sharma M, Dewan SB, et al. An antiviral sphingosine derivative from the green alga Ulvafasciata. Tetrahedron Letters. 1992;33(12):1641-1644.

28. Serkedjieva J, Konaklieva M, Dimitrova-Konaklieva S, et al Antiinfluenza Virus Effect of Extracts from Marine Algae and Invertebrates. Z Naturforsch C. 2000;55(1-2):87-93.

29. Mendes GdS, Soares AR, Martins FO, et al. Antiviral activity of the green marine alga Ulva fasciata on the replication of human metapneumovirus. Rev Inst Med trop S Paulo. 2010;52(1):3-10.

30. Aguilar-Briseño JA, Cruz-Suarez LE, Sassi JF, et al. Sulphated Polysaccharides from Ulva clathrata and Cladosiphon okamuranus Seaweeds both Inhibit Viral Attachment/Entry and Cell-Cell Fusion, in NDV Infection. Mar Drugs. 2015;13(2):697-712.

31. Hardouin K, Bedoux G, Burlot AS, et al. Enzyme-assisted extraction (EAE) for the production of antiviral and antioxidant extracts from the green seaweed Ulva armoricana (Ulvales, Ulvophyceae). Algal Research. 2016;16:233-239.

32. Sabina H, Tasneem S, Sambreen Kausar Y. Antileishmanial activity in the crude extract of various seaweed from the coast of Karachi, Pakistan. Pak J Bot. 2013;37:163-168.

33. Orhana I, Senera B, Atıcıb T, et al. Turkish freshwater and marine macrophyte extracts show in vitro antiprotozoal activity and inhibit FabI, a key enzyme of Plasmodium falciparum fatty acid biosynthesis. Phytomedicine. 2016;13(6):388-393.

34. Spavieri J, Kaiser M, Casey R, et al. Antiprotozoal, antimycobacterial and cytotoxic potential of some british green algae. Phytother Res. 2010;24(7):1095-1098.

35. Abd El-Baky HH, El Baz FK, El Baroty GS. Evaluation of Marine Alga Ulva lactuca as A Source of Natural Preservative Ingredient. AmericanEurasian J Agric \& Environ Sci. 2008;3(3):434-444.

36. Meenakshi S, Gnanambigai DM, Mozhi ST. Total flavanoid and in vitro antioxidant activity of two seaweeds of Rameshwaram coast. Global J Pharmacol. 2009;3(2):59-62.

37. Farasat M, Khavari-Nejad RA, Nabavi SMB, et al. Antioxidant Activity, Total Phenolics and Flavonoid Contents of some Edible Green Seaweeds from Northern Coasts of the Persian Gulf. Iran J Pharm Res. 2014;13(1):163-170.

38. Balaji Raghavendra Rao H, Sathivel A, Devaki T. Antihepatotoxic nature of Ulva reticulata (Chlorophyceae) on acetaminophen-induced hepatoxicity in experimental rats. J Med Food. 2004;7(4):495-497. 